\title{
BOGUSŁAW WOLAŃSKI \\ Realizacja programu duszpasterskiego »Otoczmy troską życie« w diecezji legnickiej
}

Podejmowane przez Kościół inicjatywy, by mogły przynieść oczekiwane efekty, powinny być wcześniej odpowiednio zaplanowane. Należy przeanalizować wewnętrzne i zewnętrzne warunki oraz przemyśleć środki i sposoby działania dostosowane zarówno do celów, jak i warunków. Planowanie duszpasterskie ma na celu urzeczywistnianie zbawczego dzieła Chrystusa zarówno w wymiarze jednostkowym, jak i wspólnotowym. Tworzone plany muszą być dostosowane do wymagań zasadniczego celu, powinny też współprzyczyniać się do jego osiągnięcia $^{1}$. Plan działania $w$ duszpasterstwie inaczej nazywany jest programem.

Program duszpasterski to wypracowany zakres działalności zbawczej Kościoła na okres jednego roku lub dłuższy czas, odpowiadający aktualnym potrzebom duszpasterskim. Ma on na celu usprawnienie duszpasterstwa ${ }^{2}$. Opracowywaniu programu towarzyszy przeważnie analiza sytuacji, następnie ocena tego w świetle Słowa Bożego, a potem zaproponowanie konkretnych wskazań duszpasterskiego działania. Wówczas staje się on kontynuacją misji Jezusa i w konsekwencji narzędziem ewangelizacji realizowanej przez głoszenie niezmiennych

Bogusław W O L A Ń S K I, ks. dr, wykładowca teologii pastoralnej w Seminarium Duchownym w Legnicy, dyrektor Wydziału Duszpasterskiego Kurii Biskupiej w Legnicy, Legnica, e-mail: bwolanski@intervema.com.pl

${ }^{1}$ R. K a m i ń s k i: Duszpasterstwo jako działalność zorganizowana. W: Teologia pastoralna. T. 1. Red. R. K a m i ń s k i. Lublin 2000 s. 436.

${ }^{2}$ M. O 1 s ze w s ki: Programy duszpasterskie w Polsce. W: Leksykon teologii pastoralnej. Red. R. K a mi ń s ki, W. Pr z y g o d a, M. Fi ał k o w s ki. Lublin 2006 s. 690. 
zasad w zmiennych okolicznościach życia społecznego ${ }^{3}$. W programowaniu działalności duszpasterskiej należy brać pod uwagę element boski, jakim jest łaska Boża, jak i element ludzki, czyli naturę człowieka wymagającego stałego nawrócenia. Dlatego duszpasterstwo powinno być dostosowane do ludzkich możliwości, aby boski element łaski Bożej mógł się uwidocznić ${ }^{4}$.

\section{Program duszpasterski Kościoła w Polsce na lata 2006-2010}

W marcu 2005 r. Komisja Duszpasterstwa Ogólnego Konferencji Episkopatu Polski, której wówczas przewodniczył abp Damian Zimoń z Katowic zaproponowała do realizacji w rzeczywistości Kościoła w Polsce pięcioletni program duszpasterski zatytułowany „Kościół niosący Ewangelię nadziei”. Jest on owocem refleksji nad dwoma dokumentami pastoralnymi Jana Pawła II: Novo millennio ineunte oraz Ecclesia in Europa" ". Ojciec Święty jasno wskazał, co powinien czynić Kościół na świecie, a szczególnie w Europie na progu XXI wieku. Ukazał priorytety w głoszeniu orędzia Ewangelii i sposoby działalności duszpasterskiej.

Pięcioletni program ramowy pt. „Kościół niosący Ewangelię nadziei” podzielono na pięć planów szczegółowych, które zostały przeznaczone do realizacji w kolejnych latach. Każdy rok miał swoje hasło przewodnie, które wyznaczało priorytety pastoralne do realizacji w diecezji oraz parafii. W 2005/2006 r. program został zatytułowany „Przywracajmy nadzieję ubogim”, 2006/2007 „Przypatrzmy się powołaniu naszemu”, 2007/2008 „Bądźmy uczniami Chrystusa”, 2008/2009 „Otoczmy troską życie”, 2009/2010 „Bądźmy świadkami Miłości”.

\section{Program Duszpasterski Kościoła w Polsce »Otoczmy troską życie« na rok 2008-2009}

Program „Otoczmy troską życie” zaproponowano do realizacji w Kościele w Polsce w roku liturgicznym 2008/2009. Został on przygotowany przez Komisję Duszpasterstwa Konferencji Episkopatu Polski, której przewodniczenie objął abp Stanisław Gądecki z Poznania. W programie zaakcentowano troskę o szeroko rozumiane wszystkie formy życia, które wyszły z rąk Stwórcy: życie środowiska naturalnego, życie fizyczne człowieka (sarks), życie psychiczne człowieka (psyche) i życie duchowe człowieka (pneuma) ${ }^{6}$. Jako motto biblijne wybrano

${ }^{3}$ S. Gądecki: Stowo wstęne. W: Otoczmy troska życie. Program duszpasterski Kościoła w Polsce na rok 2008/2009. Red. S. S t u ł k o w s k i. Poznań 2008 s. 7.

${ }^{4}$ M. O 1 s z e w s k i, dz. cyt., s. 690.

${ }^{5}$ D. Z i m o ń: Wprowadzenie. W: Przypatrzmy się powotaniu naszemu. Program duszpasterski Kościoła w Polsce na rok 2006/2007. Katowice 2006 s. 6-7.

${ }^{6} \mathrm{~S} . \mathrm{G}$ ą d e c k i, dz. cyt., s. 13. 
fragment Ewangelii św. Jana (10,10b): aby mieli życie i mieli je w obfitości. Jezus, Dobry Pasterz, przychodzi po to, aby owce miały życie i miały je w obfitości. Jego misją jest obdarowanie człowieka pełnią życia. Troską Boga jest, by stworzony przez Niego człowiek odkrył, że życie jest darem, zrozumiał jego piękno, potrafił się nim zachwycić i chciał żyć, wyrażając wielki szacunek do własnego życia, do życia innych ludzi oraz do stworzonego świata ${ }^{7}$. Autorzy programy wybrali także trzy fragmenty adhortacji apostolskiej Jana Pawła II Ecclesia in Europa $(90,94,96)$, które również stały się pomocą w refleksji nad troską o życie.

Program duszpasterski „Otoczmy troską życie” był logiczną konsekwencją tych, które były realizowane wcześniej w ramach programu „Kościół niosący Ewangelię nadziei”. Człowiek, który ma świadomość umiłowania, wybrania i powołania przez Boga, powinien stać się uczniem Chrystusa. Natomiast uczeń, który przeżył osobiste spotkanie ze swym Mistrzem i Nauczycielem oraz doświadczył, że w Nim było życie, sam tego życia zaczerpnął i nim żyje ${ }^{8}$.

We współczesnym świecie nietrudno zauważyć promocję „kultury śmierci”. Wielu ludzi angażuje się w działania proaborcyjne, czy też stoi po stronie eutanazji. Twierdzą przy tym, że człowiek jest właścicielem swojego życia i może z nim zrobić to, co zechce. Wielu rodziców uważa, że mogą decydować o życiu poczętego dziecka. Osłabiana jest wartość życia rodzinnego, czynione są różne eksperymenty na embrionach ludzkich. Brak wartości prowadzi do ciagłego nadużywania alkoholu, czy nieposzanowania przepisów ruchu drogowego, co w konsekwencji prowadzi do wielu wypadków. Źle pojęta wolność prowadzi również do demoralizacji i zniszczenia życia młodzieży. Można wskazywać na jeszcze inne działania współczesnego świata, które są wykroczeniem przeciwko życiu i negują prawdę, że Bóg jest dawcą życia i Bóg decyduje o jego zakończeniu.

Wyżej wymienione sytuacje pokazują, że Kościół powinien podejmować konkretne inicjatywy, by chronić życie ludzkie. Odpowiedzią na to zapotrzebowanie był program duszpasterski „Otoczmy troską życie”, który postawił sobie cele poszanowania i obrony życia. Zostały w nim zaproponowane inicjatywy katechetyczne, kaznodziejskie, rekolekcyjne i propozycje projektów pastoralnych do wykorzystania w duszpasterstwie zwyczajnym i nadzwyczajnym. Wskazano priorytety działania i zalecono do wykorzystania w posłudze nauczania, uświęcania i służby.

${ }^{7}$ K. K a n tow ski, S. S t u ł k o w s ki: Otoczmy troska życie. W: Otoczmy troska życie. Program duszpasterski Kościoła w Polsce na rok 2008/2009. Red. S. S u ł k o w s k i. Poznań 2008 s. 19.

${ }^{8}$ Tamże, s. 21. 


\section{Adaptacja programu duszpasterskiego »Otoczmy troską życie« do warunków diecezji legnickiej}

Programowanie duszpasterskie jest jednym z etapów działalności duszpasterskiej Kościoła, rozumianej jako działalność zorganizowana. Wiąże się ono z wytyczeniem celów i określeniem sposób ich najlepszej realizacji. Głównym celem planowania kościelnego jest urzeczywistnienie zbawczego dzieła Chrystusa w kierunku wewnętrznej przemiany człowieka, tak w wymiarach indywidualnych, jak wspólnotowych. Plany działania i dyrektywy muszą być dostosowane do wymagań realizacji zasadniczego celu. Cel główny, czyli wzrost w wierze, nadziei i miłości nie poddaje się bezpośredniemu planowaniu i nie jest prostym skutkiem działań duszpasterskich, bowiem zależy od łaski Boga. Można planować tylko cele pośrednie, które prowadzą do osiagnięcia celu głównego. Podejmowane planowanie duszpasterskie powinno prowadzić do pozytywnych zmian istniejącej rzeczywistości. Dlatego należy wziąć pod uwagę aktualną sytuację duszpasterską i jej analizę naukową w świetle wiary, czyli odczytywanie znaków czasu'.

Podczas programowania duszpasterskiego na poziomie diecezji, należy odwoływać się do instytucji opiniodawczo-doradczych powstałych po Soborze Watykańskim II, między innymi do Rady Kapłańskiej i Kolegium Konsulatorów oraz Diecezjalnej Rady Duszpasterskiej, która w tym procesie odgrywa szczególną rolę. Diecezjalna Rada Duszpasterska, składająca się z przedstawicieli całego Ludu Bożego, jest ważnym organem doradczym dla biskupa diecezjalnego. Dlatego powinien on doceniać jej propozycje i sugestie. Całość działań związanych z tworzeniem programu duszpasterskiego powinien koordynować Wydział Duszpasterski kurii biskupiej ${ }^{10}$. Programowanie duszpasterskie diecezji powinno dokonywać się na podstawie programu ogólnopolskiego, który zatwierdzany jest przez episkopat.

\section{Przygotowanie programu duszpasterskiego diecezji legnickiej}

Program duszpasterski diecezji legnickiej był pionierską inicjatywa, gdyż takiej propozycji jeszcze nigdy nie było w dotychczasowej historii tej wspólnoty lokalnej. Stał się on owocem pracy Wydziału Duszpasterskiego i Diecezjalnej Rady Duszpasterskiej. Grupa ludzi, świeckich i duchownych, została poproszona, by zaproponować działania pastoralne, które będą praktyczną realizacją zadanego nam programu ogólnopolskiego i będą możliwe do zrealizowania w rzeczywistości parafialnej i ponadparafialnej.

${ }^{9}$ T. W i e 1 e b s k i: Cele, sposoby, formy i środki programowania duszpasterskiego. ,Teologia Praktyczna". T. 9: 2008 s. 26-27.

${ }^{10}$ Tamże, s. 38. 
Opracowane propozycje zostały zaprezentowane podczas posiedzenia Diecezjalnej Rady Duszpasterskiej. Po przedstawionych referatach członkowie Rady mogli zadawać prelegentom pytania i przekazywać różne sugestie. Po zakończeniu dyskusji propozycja programu została zaakceptowana przez członków Rady i zatwierdzona przez biskupa diecezjalnego.

Projekty przyjęte do realizacji podczas posiedzenia Diecezjalnej Rady Duszpasterskiej we wrześniu 2008 r. objęły kilka obszarów pastoralnej działalności.

\section{Duszpasterstwo hospicyjne}

Wielu ludzi ciężko chorych przebywa w hospicjach. Potrzebują lekarstw i fachowej opieki, ale także troski duchowej. Pragną obecności drugiego człowieka, który z nimi porozmawia, posiedzi przy łóżku, przyniesie pocieszenie. Duszpasterstwo to postawiło sobie za cel rozwinięcie przede wszystkim wolontariatu młodzieżowego, który podjąłby się wyżej wymienionych zajęć. Zainicjowano również działania, by zachęcać duchownych do odwiedzania chorych w hospicjach. Powołany przez Biskupa Legnickiego duszpasterz diecezjalny zaszczepiał na terenie diecezji liczne działania proponowane i podejmowane przez Krajowe Duszpasterstwo Hospicyjne.

\section{Duchowa Adopcja Dziecka Poczętego}

Szacuje się, że każdego roku w świecie zostaje pozbawionych życia ok. 50 000000 dzieci nie narodzonych. Czy możemy pozostać obojętni na taką sytuację? Mamy bronić życia ludzkiego od poczęcia do naturalnej śmierci. Stąd program wyszedł z konkretną propozycją codziennej modlitwy w intencji dzieci nie narodzonych. Duszpasterz rodzin zachęcał, by przystapić do Duchowej Adopcji Dziecka Poczętego, co wiąże się z codziennym odmawianiem jednej dziesiątki różańca i specjalnej modlitwy. W parafii można uroczyście zainaugurować tę ideę, włączając w dzieło wielu wiernych. Każda wspólnota parafialna otrzymała stosowny rytuał, informatory i obrazki z codzienną modlitwą. Ze swoją inicjatywą wyszedł również Domowy Kościół oraz Katolickie Stowarzyszenie Młodzieży, które zaprosiło młodzież do wzięcia udziału w Marszu dla Życia w Legnicy w Niedzielę Palmową 2009 r.

\section{Parafialne grupy Honorowego Krwiodawstwa}

Wielu ludzi umiera, bo zabrakło dla nich krwi. To sytuacja, która nie może być obojętna uczniom Chrystusa. Dlatego program wyszedł z inicjatywą, by w parafiach powstawały Parafialne grupy Honorowego Krwiodawstwa. Kierowana była również zachęta, by w ramach parafii i dekanatów zorganizować dni poboru krwi. Wierni wracając z niedzielnej mszy św. mieliby wówczas okazję do konkretnego czynu - oddadzą krew, ratując wiele istnień ludzkich. 


\section{Duszpasterstwo kierowców}

Nierzadko przerażają w mass mediach relacje, w których mówi się o liczbie zabitych na drogach. Ludzie giną przez nieostrożność kierowców, nieprzestrzeganie przepisów i alkohol. Diecezjalny Duszpasterz Kierowców podjął współpracę z Policją i księżmi, by upowszechniać wśród wiernych dekalog dla kierowców. Wprowadził do kalendarium diecezjalnego dzień pamięci o ofiarach wypadków, dzień szczególnej modlitwy za kierowców i wszystkich poruszających się po drogach, Ogólnopolską Pielgrzymkę Kierowców na Jasną Górę, a także zwrócił uwagę na uroczyste świętowanie dnia św. Krzysztofa. W teczce z pomocami znalazły się również deklaracje przekazania swoich organów w razie nieszczęśliwego wypadku.

\section{Ruch Czystych Serc}

Współcześnie zagrożone jest życie w czystości wielu młodych ludzi. Łatwy dostęp do pornografii i zbyt szybka inicjacja seksualna powodują, że czystość, dziewictwo stają się wspomnieniem z przeszłości, czymś, co wzbudza ironiczny uśmiech. Sytuacja taka powoduje niepokój. Dlatego też poprzez działalność duszpasterstwa młodzieżowego i Katolickiego Stowarzyszenia Młodzieży upowszechniano na terenie diecezji Ruch Czystych Serc. Młodzi ludzie zaproszeni byli, by złożyć przed Chrystusem przysięgę życia w czystości do zawarcia małżeństwa. Oprócz ciekawych artykułów w wydaniu książkowym programu, do materiałów praktycznych został dołączony specjalny numer czasopisma „Miłujcie się oraz legitymacje dla tych, którzy zdecydują się przystąpić do Ruchu Czystych Serc. Taka inicjatywa może zostać podjęta $\mathrm{z}$ dużym powodzeniem podczas rekolekcji parafialnych dla młodzieży.

\section{Parafialne Zespoły Caritas i Szkolne Kota Caritas}

Coraz więcej ludzi na świecie nie ma co jeść, brakuje im chleba. Wymagają oni zatem naszej troski. Stąd w programie propozycja parafialnych i szkolnych kół Caritas. Działalność charytatywna, by przyniosła oczekiwane owoce musi być prowadzona mądrze. Z pomocą przyszedł Caritas. Podjęto działania, by jak najwięcej kół pomocy charytatywnej funkcjonowało w środowiskach parafialnych i szkolnych. Według danych z $2008 \mathrm{r}$. w diecezji legnickiej istniały 33 zespoły parafialne i 12 kół szkolnych. Liczby te wskazują, że ten obszar troski o życie wymagał wiele pracy.

\section{Ruch Ekologiczny św. Franciszka z Asyżu}

Życie ludzkie w znacznym stopniu zależy od środowiska naturalnego. Jak łatwo zauważyć jest one ciągle dewastowane. Potrzeba w tym względzie mądrej edukacji podjętej od najmłodszych klas w szkole. Dlatego zaproponowano Ruch Ekologiczny św. Franciszka. Działając od lat w Polsce ma on wypracowane me- 
tody pracy, z których można skorzystać w parafiach. Ruch ten może działać w każdej grupie społecznej, ucząc ochrony środowiska naturalnego.

\section{Duszpasterstwo trzeźwości}

W ciagu ostatnich lat spożycie alkoholu w Polsce wzrosło o ok. $30 \%$, a w 2007 r. wydano na niego 21,6 mld zł. Są to przerażające dane, zważywszy, że gwałtowanie wzrasta spożycie alkoholu wśród osób poniżej 18 roku życia. Liczby wskazują na konieczność bezzwłocznego zatroszczenia się o życie w trzeźwości, zwłaszcza ludzi młodych. Duszpasterstwo trzeźwości zaproponowało w programie liczne inicjatywy, które można podejmować w parafiach.

Owocem wspólnej pracy stało się wydanie książkowe Programu Diecezjalnego i zestaw pomocy, które trafiły do każdej parafii diecezji legnickiej w grudniu $2008 \mathrm{r}$.

\section{Wprowadzenie w życie programu duszpasterskiego diecezji legnickiej}

Etap organizowania jest już działaniem, zmierzającym do stworzenia warunków dla realizacji ustalonego planu. Polega on także na opracowaniu i zaprojektowaniu odpowiedniego podziału czynności. Na tym etapie szczególną rolę do odegrania ma także Diecezjalna Rada Duszpasterska i Wydział Duszpasterski kurii biskupiej.

Diecezjalna Rada Duszpasterska składa się z przedstawicieli osób duchownych i świeckich różnych duszpasterstw, stowarzyszeń oraz ruchów działających na terenie diecezji legnickiej. Zadaniem jej członków była promocja programu w środowiskach, w których żyją na co dzień. Szczególną rolę w tej kwestii odegrała również powołana w diecezji legnickiej Diecezjalna Rada Ruchów i Stowarzyszeń Katolickich. Kierownictwo Wydziału Duszpasterskiego odbyło spotkanie z prezydium rady, podczas którego omówiono zasady wprowadzenia programu diecezjalnego w życie ruchów i stowarzyszeń.

Wydział Duszpasterski, jako organ nadzorujący duszpasterstwa specjalne i specjalistyczne, podjął również działania promujące program oraz zaproponował szczegółowe rozwiązania. Zorganizowano spotkania $\mathrm{z}$ prezbiterami w sześciu rejonach diecezji. Wówczas szczegółowo omówiono działania możliwe do podjęcia w roku duszpasterskim oraz zorganizowano dyskusję, pozwalającą ubogacić przedkładane propozycje.

Prezbiterzy, wiedząc po spotkaniach, jakie wymagania w związku z programem stawia biskup diecezjalny, wnieśli program do swoich wspólnot lokalnych, gdzie wraz z Radami Parafialnymi przystosowali go do działalności parafialnej, planując oraz organizując przedsięwzięcia pastoralne. Należało wybrać z przedstawionych propozycji te, które były możliwe do zrealizowania w konkretnych 
warunkach lokalnych. Poprzez Radę Parafialną prace te mogą być inicjowane we wszystkich grupach istniejących $w$ parafii. Zalecane były także inicjatywy ponadparafialne, w obrębie dekanatów, rejonów, czy w dużych miastach.

Oprócz wyżej wymienionych działań zostało zorganizowane w formie warsztatów spotkanie świeckich przedstawicieli Rad Parafialnych. Omówiono wówczas kwestię wprowadzenia programu w życie wspólnot parafialnych. Wydział Duszpasterski zadbał również, by w prasie katolickiej, a także lokalnej prasie świeckiej ukazywały się artykuły, pokazujące możliwości realizacji przyjętych projektów pastoralnych. Podjęto także stałą współpracę z diecezjalnym radiem „Plus”. Odbyły się spotkania z katechetami świeckimi, a Akcja Katolicka zorganizowała na temat programu sympozjum naukowe.

\section{Kontrola realizacji programu duszpasterskiego $w$ diecezji legnickiej}

Funkcja kontrolowania przeplata się z funkcją planowania i organizowania. Dotyczy ona realizacji zadań zgodnie z odpowiednim wzorem, przyjętymi wymaganiami, jak również ma pomóc $\mathrm{w}$ wyciagnięciu $\mathrm{z}$ tego porównania wniosków na przyszłość. W ciagu roku duszpasterskiego funkcję tę odpowiednio podejmują: biskup legnicki przy pomocy wydziału duszpasterskiego, dziekan, proboszcz.

Na zakończenie roku duszpasterskiego została przygotowana specjalna ankieta $^{11}$, którą skierowano do wszystkich parafii. Analiza danych, które udało się uzyskać, ukazuje w jakim stopniu program został zrealizowany w diecezji i które z zaproponowanych projektów udało się zaszczepić w życie wspólnot parafialnych.

\section{Analiza wyników kontroli realizacji diecezjalnego programu duszpasterskiego »Otoczmy troską życie«}

Dane dostarczone przez parafie poprzez wypełnione ankiety nie są pełne, ponieważ na 241 parafii jedynie 147 oddało wypełnione formularze, natomiast 94 ich nie przekazało. Materiał, na podstawie którego podajemy wyniki, został uzyskany z $61 \%$ parafii diecezji legnickiej. Nie oznacza to oczywiście, że 39\% parafii nie realizowało programu duszpasterskiego. Nie mamy jednak od tych wspólnot informacji, które mogłyby być zweryfikowane ${ }^{12}$.

Obszar zainteresowania w ankiecie skupiał się wokół ośmiu filarów, jakie wyznaczał program diecezjalny.

\footnotetext{
${ }^{11}$ Tekst ankiety został umieszczony w aneksie na końcu artykułu.

12 Por. M. Kluw a k: Analiza realizacji programu duszpasterskiego diecezji legnickiej »Otoczmy troska życie». „Legnickie Wiadomości Diecezjalne”. R. 18: 2009 nr 4 (71) s. 112-116.
} 


\section{Duszpasterstwo hospicyjne}

W obszarze pierwszym chcieliśmy dowiedzieć się, czy w parafiach powstało hospicjum domowe, czy młodzież uczestniczyła w szkoleniu wolontariatu i czy temat dotyczący hospicjów był podjęty w kazaniach i (lub) na katechezie.

WYNIKI:

- hospicja domowe powstały w 3 parafiach;

- młodzież uczestniczyła w szkoleniu wolontariatu w 7 parafiach;

- temat został podjęty na kazaniu i (lub) na katechezie w 98 parafiach.

\section{Duchowa Adopcja Dziecka Poczętego (DADP)}

Drugi obszar obejmował Duchową Adopcję Dziecka Poczętego. Pytaliśmy, czy wierni przystąpili do DADP. Ile osób przyjęło na siebie zobowiązanie dotyczące modlitwy za dzieci oraz kiedy miało miejsce uroczyste przyjęcie wiernych do DADP, a także czy ten temat został podjęty w parafii, a przyjęcie wiernych do DADP nastąpi być może w przyszłości.

WYNIKI:

- w 75 parafiach wierni przystapili do DADP, było to 2977 osób;

- uroczysty obrzęd przyjęcia do DADP w większości przypadków miał miejsce 25 marca, choć występowały też inne terminy: 8 września, 11 lutego, 7 października, 2 kwietnia, 8 grudnia, 6 stycznia czy też podczas odprawiania rekolekcji;

- 58 parafii zadeklarowało gotowość do włączenia się w dzieło DADP w przyszłości.

\section{Parafialne grupy Honorowego Krwiodawstwa}

Trzecie zagadnienie dotyczyło grup honorowego krwiodawstwa. W ankiecie pytaliśmy, czy w parafii została zorganizowana grupa honorowych krwiodawców, ile osób do niej należy i kiedy zaczęła działać. Pytaliśmy także, czy w parafii/dekanacie został zorganizowany dzień poboru krwi, czy temat był podjęty w kazaniach i (lub) na katechezie oraz czy ksiądz proboszcz prosił, by wierni zgłosili się do punktu krwiodawstwa.

WYNIKI:

- w 7 parafiach powstały grupy honorowych dawców krwi. Należy do nich 195 osób;

- w 17 parafiach został zorganizowany dzień poboru krwi;

- w 77 parafiach temat był podjęty w kazaniach i (lub) na katechezie;

- w 74 parafiach księża proboszczowie zachęcali do zgłoszenia się do punktu krwiodawstwa. 


\section{Ruch Czystych Serc (RCS)}

Czwarty obszar dotyczył Ruchu Czystych Serc. Opracowanie tego zagadnienia powstało na podstawie pytań, za pomocą których próbowaliśmy ustalić, czy młodzież z parafii przystapiła do RCS, czy odbyły się na ten temat prelekcje i katechezy dla młodzieży oraz czy temat był poruszany na lekcjach religii w szkole.

WYNIKI:

- w 50 parafiach odbyły się prelekcje i katechezy dla młodzieży na temat RCS;

- w 86 parafiach temat był poruszany na lekcjach religii w szkole;

- w 3 parafiach młodzież przystapiła do RCS. Było to 18 osób.

\section{Duszpasterstwo kierowców}

Piąty obszar to duszpasterstwo kierowców. W ankiecie pytaliśmy, czy w parafii została przeprowadzona akcja rozdawania deklaracji oddania narządów w razie tragicznej śmierci, czy obchodzony był dzień szczególnej modlitwy za kierowców i poruszających się po drogach, czy były rozprowadzane książeczki kierowców, czy był uroczyście obchodzony dzień św. Krzysztofa oraz czy wierni uczestniczyli w Ogólnopolskiej Pielgrzymce Kierowców na Jasną Górę.

WYNIKI:

- w 57 parafiach została przeprowadzona akcja rozdawania deklaracji;

- w 114 parafiach był obchodzony dzień szczególnej modlitwy za kierowców i poruszających się po drogach;

- w 76 parafiach były rozprowadzane książeczki kierowców;

- z 8 parafii wierni wzięli udział w Ogólnopolskiej Pielgrzymce Kierowców na Jasna Górę;

- w 118 parafiach uroczyście był obchodzony dzień św. Krzysztofa.

Parafialne Zespoty Caritas (PZC) i Szkolne Kota Caritas (SKC)

Pytaliśmy, czy w parafii został założony PZC oraz czy w szkole na terenie parafii zostało założone SKC lub jest planowane założenie PZC albo SKC, czy w parafii rozdawane są dary dla ubogich.

WYNIKI:

- w 52 parafiach został założony PZC;

- w 25 parafiach zostało założone SKC;

- w 71 parafiach wydawane są dary dla ubogich;

- 47 parafii planuje założyć PZC lub SKC.

Ruch Ekologiczny św. Franciszka z Asyżu (REFA)

W ankiecie pytaliśmy, czy została zorganizowana prelekcja na temat ekologii oraz czy w parafii lub w szkole powstało koło REFA. 
WYNIKI:

- w 52 parafiach została zorganizowana prelekcja na temat ekologii;

- w 6 parafiach powstało szkolne koło REFA.

\section{Duszpasterstwo trzeźwości}

Pytaliśmy, czy w parafii istnieje grupa wsparcia dla ludzi z problemem alkoholowym, czy temat został podjęty w kazaniach i (lub) na katechezie, czy została zorganizowana prelekcja na temat trzeźwości i czy wierni wzięli udział w międzydiecezjalnej pielgrzymce trzeźwościowej.

WYNIKI:

- w 28 parafiach istnieją grupy dla ludzi z problemem alkoholowym;

- w 115 parafiach temat został podjęty w kazaniach i (lub) na katechezie;

- w 39 parafiach została zorganizowana prelekcja na temat trzeźwości;

- 158 osób z 27 parafii wzięło udział w mędzydiecezjalnej pielgrzymce trzeźwościowej.

Skuteczność współczesnego duszpasterstwa zależy nie tylko od znajomości pryncypiów teologicznych i uwarunkowań, w których się ono dokonuje, ale także od zasad sprawnej organizacji ${ }^{13}$. Adaptując program ogólnopolski do warunków lokalnych, podjęliśmy staranie, by przestrzegać kolejnych etapów działalności zorganizowanej, począwszy od planowania, poprzez organizowanie, koordynowanie i kontrolę. Wyniki badań wskazują, że tak przeprowadzone działanie przyniosło efekty. Choć nie są one całkowicie zadowalające, to mamy nadzieję, że kolejne lata wprowadzania programu duszpasterskiego w życie diecezji przyniesie jeszcze lepsze owoce.

W przyszłości mamy zamiar podjąć intensywniejszą pracę szkoleniową i formacyjną z prezbiterami, którzy program diecezjalny powinni adaptować wraz z Radą Parafialną do warunków lokalnych. Duchowny przekonany o słuszności zamierzeń, metod działania, uczący świeckich właściwego korzystania z programu duszpasterskiego może doprowadzić do przełomu w tym względzie. W obecnym czasie pilnym zadaniem jest ukazywanie programu jako sprzymierzeńca, a nie jako dodatkowego ciężaru w duszpasterskiej codzienności. Dla wielu parafii w Polsce zaproponowany plan pozostaje ciagle nieodkrytym wynalazkiem. Nadal potrzebna jest szeroko promocja programu duszpasterskiego, zwłaszcza tych jego elementów, które przyniosły już wymierne efekty ${ }^{14}$.

${ }^{13}$ R. K a m i ń s k i, dz. cyt., s. 443.

${ }^{14} \mathrm{~K}$. P i e c h a c z e k: Teoria i praktyka w programach duszpasterskich. Rola materiatów praktycznych dla duszpasterzy. „Teologia Praktyczna”. T. 9: 2008 s. 77-78. 


\section{ANEKS}

ANIKETA

Przewielebny Księże Proboszczu!

Od XII 2008 do XI 2009 realizowaliśmy w naszych parafiach Diecezjalny Program Duszpasterski „Otoczmy troską życie”. Ostatnim etapem działalności zorganizowanej jest kontrola tego, co udało się w tym czasie uczynić. Dlatego proszę, by zakreślić krzyżykiem ( $\square$ ), co udało się w parafii Przewielebnego Księdza dokonać. Dziękuję za poświęcony czas.

Ks. Bogusław Wolański, dyrektor Wydziału Duszpasterskiego

1. DUSZPASTERSTWO HOSPICYJNE

$\square$ powstało w parafii hospicjum domowe

$\square$ młodzież uczestniczyła w szkoleniu wolontariatu

$\square$ temat był podjęty w kazaniach lub/i katechezie

$\square$ inne.

2. Duchowa Adopcja DZIECKA PoCZĘTEGo (DADP)

$\square$ wierni przystapili do DADP

Ile osób?

Kiedy?.

$\square$ temat został podjęty, przyjęcie wiernych nastąpi w przyszłości

$\square$ inne.

3. PARAFIALNE GRUPy HonOROWEgo KRWIODAWSTWA

$\square$ w parafii została zorganizowana grupa

Ile osób?.

Kiedy?.

$\square$ w parafii/dekanacie został zorganizowany dzień poboru krwi

$\square$ temat był podjęty w kazaniach lub/i katechezie

$\square$ Ksiądz Proboszcz prosił, by zgłosili się do punktu krwiodawstwa

$\square$ inne....

4. DUSZPASTERSTWO KIEROWCów

$\square$ w parafii została przeprowadzona akcja rozdawania deklaracji oddania narządów w razie tragicznej śmierci

$\square$ w parafii był obchodzony dzień szczególnej modlitwy za kierowców i poruszających się po drogach

$\square$ były rozprowadzane książeczki kierowców

$\square$ wierni uczestniczyli w Ogólnopolskiej pielgrzymce Kierowców na Jasną Górę (III sobota maja)

$\square$ uroczyście był obchodzony dzień św. Krzysztofa (25.07)

$\square$ inne.

5. RUCH CZYSTYCH SERC (RCS)

$\square$ odbyły się na ten temat prelekcje i katechezy dla młodzieży

$\square$ temat był poruszany na lekcjach religii w szkole

$\square$ młodzież z parafii przystapiła do RCS

Ile osób?. 


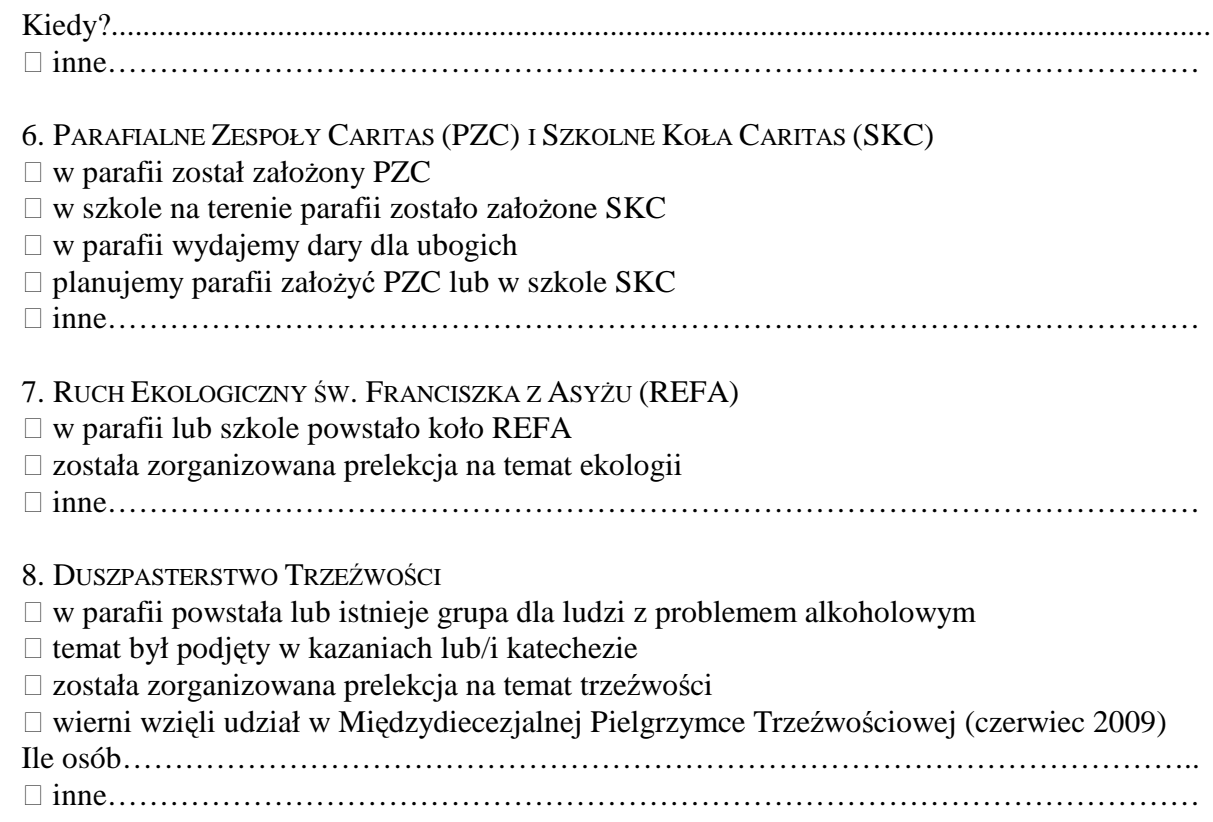

dn

pieczęć parafii i podpis ks. proboszcza 